\title{
IMPLEMENTASI PROGRAM GERAKAN LITERASI SEKOLAH (GLS) DITINJAU DARI TAHAP PENGEMBANGAN DI SD UNGGULAN AISYIYAH BANTUL
}

\author{
Hanika Triaryanti, Nur Hidayah \\ Universitas Ahmad Dahlan \\ Hanikatriaryanti31@gmail.com
}

\begin{abstract}
This study aims to study the School Literacy Movement (GLS) Implementation program which is reviewed from the Development Stage at Aisyiyah Bantul Featured Elementary School. This type of research is qualitative descriptive. The research subjects were the principal, several class teachers, and several students randomly. The research program is all things related to the School Literacy Movement (GLS) program at Aisyiyah Bantul Featured Elementary School. Data collection techniques used include observation, interviews, and documentation. Data were analyzed using the Miles and Huberman model. The validity of the data is done by source triangulation, technique triangulation, and time triangulation. The results of the study show: The School Literacy Movement (GLS) Implementation Program at the development stage has been going well, as well as covering stages (1) Planning, namely schools that make School Literacy Teams to prepare Annual Work Plans that study literacy (2), book selection reading, reading writing habits, reading the library, awarding students, making the text environment rich, literacy competitions, and public involvement, (3) Evaluation, using achievements, supporting and inhibiting factors, and the sustainability of literacy programs.
\end{abstract}

Keywords: School Literacy Movement, Development Phase

\begin{abstract}
ABSTRAK
Penelitian ini bertujuan untuk mengetahui Implementasi program Gerakan Literasi Sekolah (GLS) ditinjau dari Tahap Pengembangan di SD Unggulan Aisyiyah Bantul. Jenis penelitian ini adalah deskriptif kualitatif. Subjek penelitian adalah kepala sekolah, beberapa guru kelas, dan beberapa peserta didik secara acak. Objek penelitian adalah segala hal terkait program Gerakan Literasi Sekolah (GLS) tahap pengembangan di SD Unggulan Aisyiyah Bantul. Teknik pengumpulan data yang digunakan meliputi observasi, wawancara, dan dokumentasi. Data dianalisis dengan menggunakan model Miles and Huberman. Keabsahan data dilakukan dengan triangulasi sumber, triangulasi teknik, dan triangulasi waktu. Hasil penelitian menunjukkan: Implementasi program Gerakan Literasi Sekolah (GLS) pada tahap pengembangan sudah berjalan baik, adapun terdapat tahapan (1) Perencanaan, yaitu sekolah membuat Tim Literasi Sekolah untuk menyusun Rencana Kerja Tahunan berkaitan dengan literasi (2) Pelaksanaan, meliputi pembuatan pojok baca, pemilihan buku bacaan, pembiasaan membaca dan menulis, pemanfaatan perpustakaan, penghargaan peserta didik, menciptakan lingkungan kaya teks, lomba literasi, dan perlibatan publik, (3) Evaluasi, meliputi ketercapaian, faktor pendukung dan penghambat, serta keberlanjutan program literasi.
\end{abstract}

Kata Kunci : Gerakan Literasi Sekolah, Tahap Pengembangan 


\section{PENDAHULUAN}

Pada dasarnya membaca merupakan kegiatan untuk memperoleh dan mengolah informasi. Menurut Dalman (2013: 5) membaca dapat diartikan sebagai suatu kegiatan berpikir untuk memahami isi teks yang dibaca. Membaca merupakan salah satu kemampuan dasar yang dimiliki seseorang, terutama modal dasar peserta didik untuk belajar. Pada kenyataannya perkembangan peserta didik yang terus berkembang mengakibatkan adanya perbedaan karakteristik antara peserta didik satu dengan yang lainnya mengenai hal membaca dan menulis atau yang lebih dikenal dengan literasi. Menurut Kharizmi (2015: 15) secara sederhana literasi diartikan sebagai kemampuan membaca dan menulis atau sering disebut dengan istilah melek aksara, melek huruf, dan keberaksaraan.

Penumbuhan minat membaca terhadap peserta didik perlu sekali untuk dikembangkan. Kementrian Pendidikan dan Kebudayaan (Kemendikbud) terus mendorong minat membaca khususnya peserta didik. Salah satu yang dilakukan pemerintah adalah menerbitkan Peraturan Menteri Pendidikan dan Kebudayaan (Permendikbud) Nomor 23 Tahun 2015 tentang penumbuhan Budi Pekerti. SD Unggulan Aisyiyah Bantul sudah menerapkan program Gerakan Literasi Sekolah (GLS) sejak berdirinya sekolah tersebut. Sejauh ini pelaksanaan literasi pada tahap pembiasaan sudah dilakukan dengan pembiasaan membaca dan menulis di masing-masing kelas. Untuk mempertahankan tahap pembiasaan sekolah menerapkan tahap pengembangan, dimana tahap pengembangan bertujuan untuk mempertahankan minat membaca peserta didik terhadap suatu bacaan. Dalam penelitian ini menunjukkan implementasi program Gerakan Literasi Sekolah (GLS) ditinjau dari tahap pengembangan di SD Unggulan Aisyiyah Bantul.

\section{METODE PENELITIAN}

Jenis penelitian yang digunakan adalah penelitian deskriptif kualitatif. Penelitian ini dilaksanakan di SD Unggulan Aisyiyah Bantul yang beralamatkan di Jalan Wakhid Hasyim No. 60, Palbapang, Kecamatan Bantul, Bantul Karang, Ringinharjo, Daerah Istimewa Yogyakarta 55713. Waktu penelitian berlangsung pada bulan Februari-April 2019. Subjek penelitian meliputi kepala sekolah, beberapa guru kelas, beberapa peserta didik kelas tinggi dan peserta didik kelas rendah yang dilakukan secara acak. Objek dalam penelitian ini adalah Program Gerakan Literasi Sekolah (GLS) pada tahap pengembangan, dimana tahap pengembangan terdapat tahapan, yaitu tahap perencanaan, tahap pelaksanaan, dan tahap evaluasi. Teknik pengumpulan data dengan menggunakan observasi, wawancara, dan dokumentasi. Data kemudian dianalisis dengan menggunakan model Miles and Huberman yang terdiri dari reduksi data, penyajian data, dan penarikan kesimpulan. Sedangkan keabsahan data dilakukan dengan triangulasi sumber, triangulasi teknik, dan triangulasi waktu.

\section{HASIL DAN PEMBAHASAN}

Penelitian ini dilakukan di SD Unggalan Aisyiyah Bantul pada tanggal 12 Februari 2019 sampai 12 April 2019. SD Unggulan Aisyiyah Bantul merupakan sekolah yang sudah menerapkan program Gerakan Literasi Sekolah (GLS) sejak berdirinya sekolah, akan tetapi secara resminya program tersebut diterapkan sejak 3-4 tahun yang lalu sesuai dengan Peraturan Menteri Nomor 23 Tahun 2015 tentang Penumbuhan Budi Pekerti yang mencanangkan program Gerakan Literasi Sekolah (GLS). Latar belakang penerapan program Gerakan Literasi Sekolah (GLS) dikarenakan kurangnya minat peserta didik 
untuk membaca buku dan mengunjungi perpustakaan sekolah meskipun telah disediakan fasilitas-fasilitas yang mendukung kegiatan literasi. Akibatnya kemampuan berpikir kritis dan keterampilan peserta didik kurang. Dengan demikian diterapkannya program Gerakan Literasi Sekolah (GLS) ini bertujuan untuk meningkatkan kemampuan peserta didik dalam mengembangkan potensi dan keterampilan yang dimilikinya. Data yang diperoleh dari implementasi program Gerakan Literasi Sekolah (GLS) ditinjau dari tahap pengembangan di SD Unggulan Aisyiyah Bantul sebagai berikut :

\section{Perencanaan Program Gerakan Literasi Sekolah}

Pada tahap perencanaan tentang Implementasi Program Gerakan Literasi Sekolah (GLS) di SD Uggulan Aisyiyah Bantul membutuhkan banyak pihak yang terlibat dalam penyusunan program diantaranya kepala sekolah, waka kurikulum sekolah, pimpinan yayasan, guru kelas, dan seluruh warga sekolah. SD Unggulan Aisyiyah Bantul melakukan perencanaan program untuk meningkatkan program literasi tersebut dengan membentuk Tim Literasi Sekolah (TLS) dengan beranggotakan 16 anggota dari guru-guru kelas yang di ketuai oleh bapak kepala sekolah. Tim Literasi Sekolah (TLS) bertugas mengatur jalannya dan lancarnya program literasi dengan membuat Rencana Kerja Tahunan dimana terdapat agenda yang berkenaan dengan literasi. Selain itu guru kelas juga merencanakan program literasi dengan pembuatan pojok literasi sesuai dengan program kerja Tim Literasi Sekolah (TLS).

2. Pelaksanaan Program Gerakan Literasi Sekolah

Penjabaran program Gerakan Literasi Sekolah pada tahap pengembangan sebagai berikut.

a. Pojok Baca

Pojok baca terdapat di masing-masing kelas yang dibuat oleh guru kelas. Pojok baca ini letaknya di sudut ruangan kelas. Penataan pojok baca di masing-masing kelas berbedabeda sesuai kreativitas guru. Ada buku bacaan yang diletakkan di lemari, ada yang buku bacaan digantung seperti jemuran baju, dan ada juga yang diletakkan di rak buku. Kemudian area pojok baca ada yang dihias-hiasi oleh pernak-pernik dan ada juga yang hanya polosan. Adanya pojok baca di kelas ini digunakan untuk menarik perhatian peserta didik untuk membaca dan mendekatkan peserta didik dengan buku bacaan.

b. Buku Bacaan

Buku bacaan yang disediakan di pojok baca untuk kegiatan literasi adalah buku-buku non pelajaran, seperti cerita rakyat, dongeng, cerita nabi dan rosul, ensiklopedia, komik, novel, majalah anak. Peserta didik dibebaskan untuk memilih buku bacaan yang disukainya. Buku-buku yang ada di pojok baca biasanya dibaca pada saat kegiatan literasi membaca, jam istirahat, dan saat jam kosong.

c. Pembiasaan Membaca dan Menulis

Kegiatan membaca sebelum pembelajaran rutin dilakukan di SD Unggulan Aisyiyah Bantul setiap pagi sebelum kegiatan belajar mengajar dimulai. Setiap pagi peserta didik melakukan kegiatan rutin yaitu tadarus, shalat dhuha, dan pembiasaan membaca buku. Setelah peserta didik membaca, kemudian guru kelas meminta untuk menuliskan di kartu jurnal literasi atau hanya sekedar menyampaikan apa yang dibaca di depan temantemannya. Kegiatan pembiasaan membaca dan menulis dilakukan sesuai dengan jadwal pembiasaan di masing-masing kelas.

d. Pemanfaatan Perpustakaan Sekolah

Perpustakaan di SD Unggulan Aisyiyah Bantul bernama "MINTERKE" yang merupakan singkatan dari Membaca Intensif TERpadu untuk Kemajuan. Perpustakaan. 
Terdapat koleksi bacaan yang lengkap mulai dari buku pelajaran, buku non pelajaran, dan buku-buku lainnya. Perpustakaan sekolah dimanfaatkan untuk berbagai kegiatan sekolah antara lain membaca buku, meminjam buku, pemutaran film dan kegiatan pembelajaran.

e. Penghargaan Peserta Didik

Sekolah akan memberikan penghargaan kepada peserta didik yang berbakat dan memiliki prestasi. Peserta didik yang berhasil meraih juara dalam perlombaan maka akan diberikan tropi, seritifikat, dan uang pembinaan dari penyelenggaran lomba sekaligus dari sekolah. Adapun penghargaan dari kegiatan literasi yaitu peserta didik mendapat alat tulis, jajan, dan bintang yang ditempelkan didinding kelas untuk ditukarkan dengan nilai tambahan.

\section{f. Menciptakan Lingkungan Kaya Teks}

Untuk menciptakan lingkungan kaya teks dengan membuat poster dan slogan yang berisi ajakan yang ditujukan kepada peserta didik. Poster dan slogan ditempel di lingkungan sekolah, seperti di ruang kepala sekolah, ruang tata usaha, ruang perpustakaan, ruang kelas, dan halaman sekolah yang sering dilewati peserta didik. Tujuan ditempelkannya poster dan slogan ini adalah untuk mengingatkan peserta didik.

g. Lomba Literasi

Sebagai wujud dari program Gerakan Literasi Sekolah (GLS) sekolah mengadakan lomba terkait literasi. Kegiatan lomba literasi diadakan sekolah saat ada peringatan hari nasional atau hari bersejarah. Lomba tersebut diantaranya lomba mading, lomba menulis surat, lomba menulis pengalaman sehari-hari dan lomba bulan bahasa. Selain lomba yang diadakan sekolah, sekolah juga mengirimkan peserta didik yang berprestasi untuk mengikuti lomba di luar sekolah baik lomba akademik maupun non akademik.

h. Perlibatan Publik

SD Unggulan Aisyiyah Bantul melakukan kerjasama untuk mendukung program Gerakan Literasi Sekolah (GLS) dengan berbagai pihak luar sekolah seperti penerbit buku, ibu-ibu dari perkumpulan Aisyiyah, perpustakaan daerah, guru-guru terdekat dari sekolah, dan sekolah yang sudah memiliki literasi baik. Untuk guru kelas sendiri mempunyai sebuah forum diskusi yang rutin melakukan pertemuan setiap 1 minggu sekali guna membahas kegiatan literasi di kelas masing-masing.

3. Evaluasi Program Gerakan Literasi Sekolah

a. Ketercapaian Program Gerakan Literasi Sekolah

Ketercapaian dalam program Gerakan Literasi Sekolah di SD Unggulan Aisyiyah Bantul meliputi kegiatan-kegiatan yang menyenangkan peserta didik. Dari kegiatan yang dilakukan meningkatkan perkembangan membaca peserta didik, peserta didik menjadi semangat membaca dari adanya pojok baca dan buku bacaan yang menarik serta memunculkan rasa ingin tahu yang tinggi. Bukan hanya peserta didik, capaian literasi juga memunculkan sikap ramah, empati, dan terdapat jalinan komunikasi yang baik antar warga sekolah.

b. Faktor Pendukung dan Penghambat Program Gerakan Literasi Sekolah

Faktor pendukung tersebut antara lain perpustakaan sekolah, pojok baca, koleksi buku bacaan terbaru, pembiasaan membaca, sponsor dan kerjasama dari luar sekolah, serta pembiayaan dari sekolah maupun luar sekolah. Sedangkan faktor penghambatnya antara lain masih terdapat peserta didik yang belum lancar dalam membaca sehingga memerlukan bimbingan guru, motivasi peserta didik untuk membaca kurang, dan kurangnya rasa kesadaran peserta didik untuk merawat fasilitasi yang telah disediakan sekolah.

c. Keberlanjutan Program Gerakan Literasi Sekolah 
Keberlanjutan program Gerakan Literasi Sekolah (GLS) diantaranya akan meningkatkan program dari segi ruang akan lebih menambah ruang-ruang yang dilengkapi dengan buku bacaan, koleksi buku bacaan akan diperbarui sesuai buku terbaru, dan pembiasaan membaca setiap hari yang ditingkatkan. Sekolah juga akan mengadakan berbagai macam lomba bukan hanya lomba yang telah dilaksanakan.

\section{SIMPULAN}

SD Unggulan Aisyiyah Bantul menerapkan program Gerakan Literasi Sekolah sejak 3-4 tahun yang dilatarbelakangi oleh kurangnya minat membaca buku dan berkunjung ke perpustakaan. Adapun implementasinya antara lain: (1) Perencanaan, Perencanaan, yaitu sekolah membuat Tim Literasi Sekolah untuk menyusun Rencana Kerja Tahunan berkaitan dengan literasi (2) Pelaksanaan, meliputi pembuatan pojok baca, pemilihan buku bacaan, pembiasaan membaca dan menulis, pemanfaatan perpustakaan, penghargaan peserta didik, menciptakan lingkungan kaya teks, lomba literasi, dan perlibatan publik, (3) Evaluasi, meliputi ketercapaian, faktor pendukung dan penghambat, serta keberlanjutan program literasi.

\section{DAFTAR PUSTAKA}

Dalman. 2013. Keterampilan Membaca. Jakarta: PR Rajagrafindo Persada.

Kemendikbud. 2016. Panduan Gerakan Literasi di Sekolah Dasar. Jakarta: Direktorat Jenderal Pendidikan Dasar dan Menengah Kementerian Pendidikan dan Kebudayaan.

Kharizmi, Muhammad. 2015. Kesulitan Siswa Sekolah Dasar Dalam Meningkatkan Kemampuan Literasi. JUPENDAS. Vol II. No. 2. Hal 15

Sugiyono. 2017. Metode Penelitian Pendidikan. Bandung: Alfabeta. 